\title{
A Spatial Equilibrium Analysis of Policy for the Forestry and Wood-Processing Industries in Northern Vietnam
}

\author{
Phan Sy Hieu ${ }^{1}$, Steve Harrison ${ }^{2}$, David Lamb ${ }^{3}$ \\ ${ }^{1}$ The Informatics and Statistics Centre for Agriculture and Rural Development, The Ministry of Agriculture \\ and Rural Development, Hanoi, Vietnam \\ ${ }^{2}$ The School of Economics, The University of Queensland, Brisbane, Australia \\ ${ }^{3}$ Rainforest Cooperative Research Center and School of Integrative Biology, University of Queensland, \\ Brisbane, Australia \\ E-mail:hieu_ps@yahoo.com,s.harrison@uq.edu.au,d.lamb@uq.edu.au \\ Received January 28, 2011; revised March 11, 2011; accepted April 15, 2011
}

\begin{abstract}
National objectives for forestry and wood-processing industries have not usually been achieved to the extent that the Government of Vietnam planned. A spatial equilibrium model with linear supply and demand functions for the forestry and wood-processing industries was developed to analyse policies for northern Vietnam. Four policy scenarios were established, in each of which optimal levels of prices, supply and demand quantities were estimated, and solutions were subjected to sensitivity analysis with respect to the elasticity estimates. The analysis indicates that government objectives cannot be achieved in the 2010-2015 period because plans if implemented would force the main stakeholders to produce unprofitable quantities. For greater financial viability and sustainability, the number of planned new wood-processing factories should be reduced and the design production capacity of each new factory should be increased to achieve economies of size and international market competitiveness. Also, the area of planted production forest in northern Vietnam will increase in all four policy scenarios; however, the growth should be lower than the levels planned for 2015 .
\end{abstract}

Keywords: Five-Year Governmental Plan, Policy Scenario, Supply Target, Engineered Wood Products, Asia, Vietnam

\section{Introduction}

Globally the area of natural forest has gradually declined and as a result many countries have sought to increase their forest plantation area. The increase has contributed to biodiversity, environment protection and economic growth in many countries. A consequence is that development of wood-processing industries has been undergoing change, with greater use of plantation timber.

National objectives can be presented in qualitative and quantitative targets for a given period of time, for instance one year and five years. Some countries regularly devise five-year plans for forestry and wood-processing industries. Qualitative and quantitative objectives are usually specified for the final year of each five-year period, for example 2000, 2005, 2010, 2015 and 2020 as in Vietnam [1] and 2002, 2007, 2012 and 2017 as in India [2].

Qualitative objectives are usually presented as the in- crease in the participation of private sectors in timber plantation establishment, the expansion of the woodprocessing industry, and the increase in incomes of people including the poor who manage plantation forest in upland and remote regions. In Vietnam, the qualitative objective of the national government has been that Vietnam will become self-sufficient in terms of domestic production of wood and wood-processing products. In the plan, the domestic forestry industry will supply approximately enough input for the wood-processing industry, and the domestic production of the wood-processing industry will not only meet the domestic demand but also leave some surplus for export [3].

Key and measurable qualitative objectives are usually quantified in forestry plans. For example, the Indian government targeted that the national forest cover would increase from $25 \%$ in 2007 to $33 \%$ in 2012 [4]. In Bhutan, one of national targets is to maintain the current forest cover of $60 \%$ [5]. In Vietnam, a forest cover of $43 \%$ 
was set in 1998 for 2010 [6]. More specifically, the Government of Vietnam [GoV) set supply targets to be achieved by 2010, 2015 and 2020 for wood and woodprocessing products. For example, the national supply quantity planned is 5 million tonnes (Mt) for paper products and $6 \mathrm{Mt}$ of sawn-timber in 2020 [3,7]. These national quantitative supply targets are divided between provinces. The GoV assumed that when the set of supply targets are met, the problems existing in the wood and wood-processing industries will generally be solved; for instance unprofitable farm-gate prices, high production cost of domestic pulp and paper products and shortage of industrial jobs in rural areas will be overcome [3].

To achieve national forestry objectives, policies in three broad areas are usually considered for implementation by governments. The first policy group relates to the private ownership of plantation forest land, with governments proposing the transfer of more forest land to famers and local communities rather than to state organizations, as in Philippines [7] and Vietnam [8]. The second group is policies of timber exploitation from natural forests. The exploitation is usually banned (as in Vietnam during 1992-1998), or highly limited as in Vietnam [8], the Philippines [7] and Australia [9]. The third policy group considers how to manage timber markets effectively or how wood markets work competitively, as in Philippines [7] and Bhutan [5]. Besides policy groups, changes of governmental institutions are usually planned in many countries, including Cambodia [10], Vietnam [8,11], the Philippines [7] and Mongolia [12]. These institutional changes aim to make government forestry policies func- tion more effectively.

In the case of Vietnam, the GoV has developed policies in two main areas, namely to increase investment in expanding the design production capacity of existing large-scale state-owned enterprises and to build new largescale wood-processing enterprises. To increase the supply of logs, the GoV implemented the Five Million Hectare Reforestation Program (5MHRP) over 1998-2010 [13].

Globally, national qualitative and quantitative objecttives for forestry and wood-processing industries are often unachievable, for instance in Bhutan [5], the Philippines [7] and India [4]. For example, in India, according to Joshi et al. (2010) [4] only three states in the total of 28 states and 7 union territories will meet the planned forest cover of $33 \%$. A common reasons reported for failures in these countries is weak policy and institution frameworks that make markets work inefficiently, for instance the high marketing cost in the Philippines [7]. Other reasons relate to insufficient funds from governments, for example in Mongolia [12], and high rates of poverty in upland regions, e.g. greater than $90 \%$ in Viet- nam [8] and in the Philippines [7]. In these regions, local people have focused on short-term enterprises and particularly annual crops rather than long-term income sources including planting timber trees.

In Vietnam, the forestry and wood-processing Industries have made major advances in the last 20 years. The area of plantation forest increased from only about $0.2 \mathrm{M}$ ha in 1992 to $1.7 \mathrm{M}$ ha in 2006 [14] and to $2.77 \mathrm{M}$ ha in 2008 [15]. The wood-processing industry expanded rapidly in the first decade of the 2000s. The average growth of export revenue was more than $30 \%$ annually during 2001-2007. Total export revenue was 61 million USD in 1996, 1.55 billion USD in 2005, 2.2 billion USD in 2006 and 3.2 billion USD in 2008. However, as in other developing countries, these achievements were much lower than what the national government had planned. In 2005, only two new wood-processing enterprises were built in northern Vietnam, in comparison to the planned 14 new enterprises. The plan of building a state-owned paper factory in Kon Tum province was abandoned in 2003 due to the lack of raw materials [16]. The annual growth of the area of planted production forest in Vietnam was only $4 \%$, compared with the planned growth of $6 \%$ in the $1998-2008$ periods. In $2006,80 \%$ of the wood requirement for the furniture sub-industry was imported. The GoV had to adjust the planting area target of $5 \mathrm{M}$ ha to only $3 \mathrm{M}$ ha in 2010 [17].

Spatial equilibrium modeling provides an appropriate framework for analysis of national forestry policies. A theoretical spatial equilibrium model with linear supply and demand functions was developed by Takayama and Judge, initially in 1964 and fully in 1973 [18]. The theoretical model inspired many studies for various products and policies, for example Adams et al. [19] for timber in north America, Jae [20] for southern pine lumber in the USA, Goletti et al. [21] for the rice sector in Vietnam, Kawaguchi et al. [22] for milk markets in the Japanese dairy industry, Yoshimoto et al. [23] for Japanese timber markets, Agrifood Consulting International for the livestock sector in Vietnam [24], Stennes et al. [25] for lumber in the USA and Canada, and Devadoss et al. [26] for softwood lumber in the USA, Canada, Mexico, China, Japan, New Zealand, Australia and European Union.

per spatial equilibrium modelling (SEM) is used to explain why there is a gap between plans and observed growth for the forestry and wood products industries in northern Vietnam and to draw policy implications from SEM applications. The next sections describe notable factors - that were not considered by the GoV-affecting the supply targets, as well as the structure of the spatial equilibrium model developed. The method of data collection and contents of four policy scenarios are presented, and sensitivity testing relation to elasticity esti- 
mates is described. Finally the interpretation of optimal solutions generated between the four policy scenarios is examined and policy implications are drawn.

\section{Factors Affecting the Government of Vietnam's Supply Targets for Wood and Wood-Processing Products}

Many factors that were not taken into account by the GoV in 2006 can affect supply targets for the forestry sector. Three main factors are clearly identified by research conducted by Katja et al. [27], Barney [29] and GTZ [28], namely the change of import taxes, the relationship between design production capacities of paper factories and average production cost, and distances between wood-processing factories and unit transportation costs.

\subsection{Declining Protection for Domestic Wood Industries}

Vietnam's trade policy has changed greatly since 1994 when the USA discontinued their embargo on Vietnam's international trade. In 1995, Vietnam became an official member of the Association of South East Asia Nations (ASEAN) and joined the ASEAN Free Trade Association (AFTA). By 2006, Vietnam had implemented provisions of AFTA of reducing tariffs on imported products typically ranging from $30 \%$ to $100 \%$, to less than $5 \%$, including the import taxes on paper and furniture products from ASEAN. In 1998, Vietnam became an official member of the Asia Pacific Economic Cooperation (APEC). In 2000, the USA normalised its relationship with Vietnam in terms of bilateral trade policies. In December 2006, Vietnam was accepted as an official member of the World Trade Organization (WTO). All these changes have made Vietnam's trade policies more consistent with world trade policies. Import and export taxes have been reduced, and are planned to be gradually further reduced to from $0 \%$ to $5 \%$ by 2015 . Import taxes on paper in $2008(40 \%)$ and furniture products in 2008 (33\%) from non-ASEAN countries were also reduced to only $5 \%$ in $2010[29,30]$. The declining prices of these products have gradually affected the supply quantities of most domestic factories, for instance reducing the domestic supply quantities of paper products.

\subsection{High Average Production Costs and Low Design Production Capacities of Domestic Paper Factories}

Wood-processing factories in Vietnam have relatively low production scales in terms of capital investment, number of employees and design production capacity. The design production capacities of paper factories vary greatly, from only 1000 tonnes up to 300,000 tonnes per year. For example, although Vietnam has about 300 paper enterprises which could produce in total about 950 000 tonnes of paper in 2006, the three largest stateowned paper enterprises, namely Bai Bang, Tan Mai and Dong Nai, accounted for more than $50 \%$ of the total paper production in Vietnam in 2000 [29], and 40\% in 2006. The supply quantities of the above three largest paper factories were about 200,000, 140,000 and 50,000 tonnes respectively in 2006 [6].

According to Roda et al. [31], only 20 paper factories had design production capacities exceeding 10,000 tonnes a year. Therefore, the domestic production cost of paper varied greatly, from 764 to 877 USD per tonne, while the average production cost of paper products in ASEAN countries was only 685 USD per tonne in 2006 [32]. The Cost Insurance and Freight (CIF) prices of paper products imported from Indonesia and Thailand through Vietnam seaports ranged from 822 to 842 USD per tonne in 2006 [32]. Therefore, domestic paper products can be competitive only if taxes on imports are sufficiently high; otherwise, only large-scale pulp and paper factories are competitive. For example, the production cost of Bai Bang state-owned paper enterprise (BA$\mathrm{PACO}$ ) in 2006 was 764 USD per tonne. According to Katja et al. [27] and GTZ (2007) [28], the design production capacities of paper factories should be at least 300,000 tonnes a year to achieve sufficient economies of scale for international price competitiveness.

\subsection{Spatial Distribution of Wood-Processing Factories and Proximity to Timber Resources}

The spatial locations of wood-processing factories and their proximities to timber resources affect the supply quantities of timber and wood-processing products and their prices. For example, if other factors are constant, the more factories are built in one area of timber resource the greater the demand for timber and the higher the timber prices will be. If the number of wood-processing factories is too great and the supply of timber is limited, the prices of timber will increase and the timber quantity purchased by each factory will fall. Consequently, the supply quantity and price of a wood-processing product from each factory declines while its average production cost increases. If the price is lower than the average production cost for a new factory, the new factory should not be built. The GoV's plan to build wood-processing factories did not take into sufficient consideration the distance between factories and wood plantation size. 
According to ADB [32] and Barney [29], a factory generally could operate profitably if located within a distance of $200 \mathrm{~km}$ from a main raw material supply area. No data about the distances between wood-processing factories are published in Vietnam, although Phan et al. [6] estimated that the average distance between provinces having existing and planned new large-scale wood-processing factories is only $142 \mathrm{~km}$. In addition, some provinces plan to have more than one large-scale wood-processing factory, including Phu Tho, Hoa Binh, Bac Kan, Lang Son and Quang Ninh provinces. Therefore, the average distance between these wood-processing factories may become much less than $142 \mathrm{~km}$. The short distances between these factories can lead to the above situation where there will be insufficient resource for the factories to be all large.

\section{Research Method}

The research method includes three main activities: identifying the components of the industry and stakeholders in the supply chain of wood and wood-processing products; formulating the spatial equilibrium model for forestry and wood-processing industries; and collecting data to populate the SEM.

\subsection{The Classification of Wood and Wood-Processing Sub-Industries and Their Products}

Phan et al. [11] classified the wood-processing industry in northern Vietnam into six sub-industries with seven main input and output products, namely woodchip, sawn wood, engineered wood, pulp, paper, engineered- wood furniture and solid wood furniture, as in Figure 1.

The selection of regions of the spatial equilibrium model was restricted by availability of provincial data in northern Vietnam (defined as from Ninh Binh province to the northern border of Vietnam). For example, the transportation costs of timber are only available between some provinces only, as reported in ICARD ([33,34]), Nguyen et al. [36] and Lamb et al. [37]. Distances

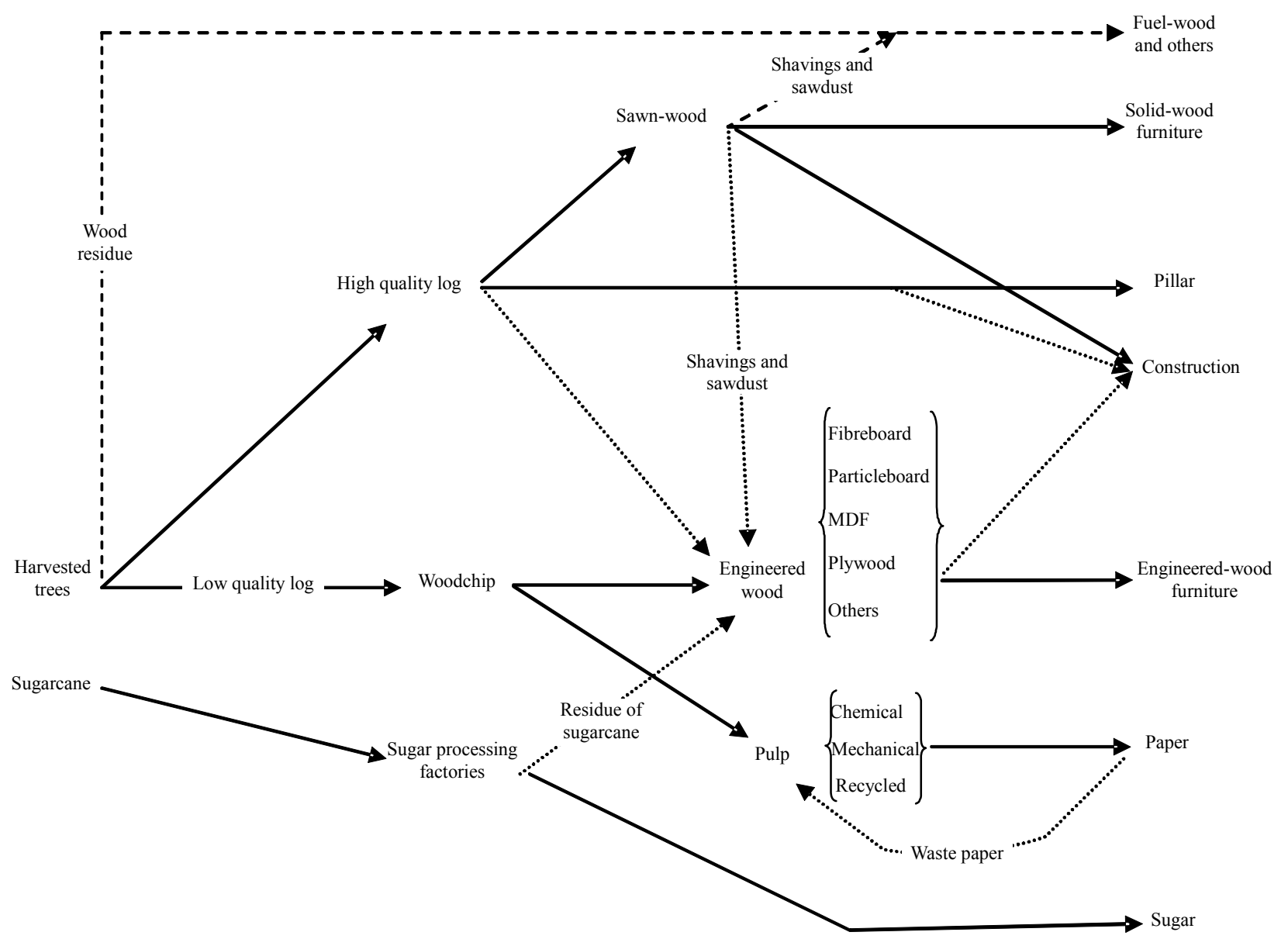

Figure 1. Inputs and outputs for manufacture of intermediate and final wood-processing products. Source: ICARD [34], ICARD [35], Barney [29], Nguyen et al. [35], Nguyen et al. [36], Lamb et al. [37] and Phan et al. [6]. 
between provinces in northern Vietnam have been reported by Phan et al. [6], but are not available for southern Vietnam (defined as from Thanh Hoa province to the southern border of Vietnam).

Table 1 lists nine products representing the main inputs and main outputs purchased and produced by seven main stakeholders in 26 regions (i.e. provinces and cities) in northern Vietnam and three regions outside northern Vietnam. The 29 regions include Hanoi, Vinh Phuc, Bac Ninh, Ha Tay, Hai Duong, Hai Phong, Hung Yen, Thai Binh, Ha Nam, Nam Dinh, Ninh Binh, Ha Giang, Cao Bang, Bac Kan, Tuyen Quang, Lao Cai, Yen Bai, Thai Nguyen, Lang Son, Quang Ninh, Bac Giang, Phu Tho, Dien Bien, Lai Chau, Son La, Hoa Binh. The three other regions are the rest of Vietnam, ASEAN countries and the rest of the world.

The seven main stakeholders are planters (i.e. farmers, state forestry enterprises and other planters), operators of woodchip factories, pulp factories, paper factories and engineered-wood factories, owners of sawmills, furniture producers and consumers. The nine products include low quality log, high quality log, sawn timber, woodchip, engineered wood, pulp, paper, solid-wood furniture and engineered-wood furniture.

\subsection{Formulation of the Spatial Equilibrium Model $^{1}$}

A spatial equilibrium model was developed which has three groups of linear functions, namely supply functions, demand functions and an objective junction of the totaleconomic surplus after subtracting the total transportation cost between regions. This model may be summarized as:

Demand functions: $\quad p_{k, i}=\alpha_{k, i}-\sum_{k^{\prime}=1}^{K} \beta_{k, k^{\prime}, i} D_{k^{\prime}, i}$

Supply functions: $r_{k, i}=\theta_{k, i}-\sum_{k^{\prime}=1}^{K} \varpi_{k, k^{\prime}, i} S_{k^{\prime}, i}$

Objective function:

$$
f(D, S, Q)=\sum_{i=1}^{I} \sum_{k=1}^{K}\left(\int p_{k, i} d D_{k, i}-\int r_{k, i} d S_{k, i}-\sum_{j=1}^{J} C_{k, i, j} Q_{k, i, j}\right)
$$

The model has following six groups of constraint in-

${ }^{1}$ For more detail see the journal article 'A Review of the Formulation and Application of the Spatial Equilibrium Models to Analyze Policy' written by the author. The journal article was accepted to publish on 4 February 2011 by the Journal of Forestry Research [38]. The journal article reviewed how the spatial equilibrium model is developed and applied. The journal article also presented various methods that can be applied to solve spatial equilibrium models. Finally, the journal article described how to interpret the solutions generated when the model is solved in the software of General Algebraic Modeling System (GAMS) The author's programming file written in GAMS to solve spatial equilibrium models by linear programming, non-linear programming and mixed complementary programming was also accepted to publish in the website of GAMS on October 2010 [39]. equalities and equalities.

\begin{tabular}{ll}
\hline$p_{k, i}=r_{k, i}$ & $\begin{array}{l}\text { Supply price and demand price must be equal } \\
\text { by commodities (k) and regions (i) }\end{array}$ \\
\hline$p_{k, i}-p_{k, j} \leq C_{i, j}$ & $\begin{array}{l}\text { The differences of demand prices of commodi- } \\
\text { ties (k) between regions (i) must be smaller } \\
\text { than the unit transportation costs (C). }\end{array}$ \\
$\sum_{j=1}^{R} S_{k, i}=\sum_{j=1}^{R} D_{k, i}$ & $\begin{array}{l}\text { Total supply of commodity } k \text { from all regions } \\
\text { must be equal to the total demand of commod- } \\
\text { ity } k \text { from all regions }\end{array}$ \\
$\sum_{j=1}^{R} Q_{k, i, j}=S_{k, i}$ & $\begin{array}{l}\text { Total quantity transport of commodity } k \text { from a } \\
\text { region } i \text { to all regions } j \text { must be equal to total } \\
\text { supply of commodity k in region } i .\end{array}$ \\
$\sum_{i=1}^{R} Q_{k, i, j}=D_{k, j}$ & $\begin{array}{l}\text { Total quantity transport of commodity } k \text { from } \\
\text { all regions } i \text { to a regions } j \text { must be equal to total } \\
\text { demand of commodity } k \text { in region } j .\end{array}$ \\
$p_{k, i}, r_{k, i}, Q_{k, i, j} \geq 0$ & $\begin{array}{l}\text { All variables (supply prices, demand prices and } \\
\text { quantity transported among regions) are } \\
\text { nonnegative. }\end{array}$ \\
\hline
\end{tabular}

The symbols in above functions, equalities and inequalities are as follows.

\begin{tabular}{llll}
\hline$i$ & Region $i, \quad i=1,2, \cdots, R$ & $\mathrm{~S}$ & Supply quantity \\
\hline$j$ & Region $j, \quad j=1,2, \cdots, R$ & $\mathrm{p}$ & Demand price \\
$k$ & Product $k, \quad k=1,2, \cdots, K$ & $\mathrm{r}$ & Supply price \\
$k^{\prime}$ & Product $k^{\prime}, \quad k^{\prime}=1,2, \cdots, K$ & $\alpha$ & $\begin{array}{l}\text { Constants of demand } \\
\text { functions }\end{array}$ \\
$Q$ & $\begin{array}{l}\text { Transportation quantity } \\
\text { between regions }\end{array}$ & $\theta$ & $\begin{array}{l}\text { Constants of supply } \\
\text { functions }\end{array}$ \\
$C$ & $\begin{array}{l}\text { Unit transportation cost } \\
\text { between regions }\end{array}$ & $\omega$ & $\begin{array}{l}\text { Price coefficients of } \\
\text { supply functions }\end{array}$ \\
$D$ & Demand quantity & $\beta$ & $\begin{array}{l}\text { Price coefficients of } \\
\text { demand functions }\end{array}$ \\
\hline
\end{tabular}

In the spatial equilibrium model, supply and demand prices $^{2}$, supply quantities, demand quantities and traded quantities are endogenous variables. By maximizing the objective function subject to the above six groups of constraint inequalities and equalities, optimal levels of these endogenous (policy) variables are found. As an example of a change in policy, suppose a new paper factory is to be built in a province. This will create a new supply function for paper in that province, and lead to new optimal levels of endogenous variables. The comparison between old and new optimal solutions indicates the affect of the policy on prices, supply quantities, demand ${ }^{2}$ In economics theory, scholars usually want to separate the behaviour of consumers and producers and then prove that if consumers and producers try to maximize their own economic benefits then the interaction between them will lead to equality of supply price and demand price. As a result, in theoretical mathematical-economic models, supply prices are expressed in supply functions and demand prices are expressed in demand functions. 
Table 1. Main inputs and main outputs of stakeholders in the spatial equilibrium model for wood and wood-processing industries in northern Vietnam.

\begin{tabular}{lcc}
\hline Stakeholder & Major input (demand quantity) & Major output (supply quantity) \\
\hline Planters & Area of planted production forest & Low quality logs \\
& Low quality log & Woodchip \\
Operators of woodchip factories & High quality log & Pulp \\
Operators of pulp factories & Woodchip & Sawn-timber \\
Owners of sawmills & High quality logs & Writing paper \\
Operators of Paper factories & Pulp & Engineered wood \\
Operators of Engineered-wood factories & Woodchip & Solid-wood furniture \\
Furniture producers & Sawn timber & Engineered-wood furniture \\
& Engineered wood & Writing paper \\
Consumers & Solid-wood furniture & Assumption: consumers do not produce any \\
\end{tabular}

quantities, traded quantities and the total economic surplus.

\subsection{Data Collection Method}

The establishment of the spatial equilibrium model for the forestry and wood-processing industries in northern Vietnam requires three groups of data: main policies affecting the operation of the two industries; own-price, cross-price and income elasticity of supply and demand functions; and prices, supply quantities and demand quantities of the nine wood and wood-processing products in the base year, 2008. The main policies - about trade and investmenthave been obtained from published reports of official state organisations, particularly the Vietnam General Department of Custom (GSO) and the Vietnam Ministry of Agriculture and Rural Development (MARD).

For the data group of price and income elasticities, according to Phan et al. [6], data published about wood and wood-processing products usually are discon- tinuous, inconsistent between major organisations and are irregularly updated. As a result, data available in Vietnam is not adequate to estimate these elasticities, and hence it has been necessary to rely on estimates reported in international econometrics journals, referred to here as external elasticities. For example, Hseu et al. [40] applied econometric methods to estimate own-price and cross-price elasticities of input demand and output supply in the pulp and paper industry in the USA and Can- ada. McCarthy et al. [41] reported estimates of income elasticities and demand price elasticities of pulp and paper products in Asia, Europe, North and South America. Waggener et al. [42] estimated own- price elasticity of supply of sawn-timber in Indonesia. Stennes et al. [25] estimated own-price elasticity of demand for lumber in America. Turner et al. [43] estimated own-price elasticity of demand for furniture products. McCarthy et al. [41] estimated own-price elasticity of supply for industrial roundwood in New Zealand.

For the data group of prices, supply and demand quantities of wood and wood-processing products in 2008, the inconsistent data published meant that it was necessary to standardize concepts and conversions rates. Four main steps were conducted to establish the single dataset for the model, as described schematically in Figure 2.

Step 1: A literature review was conducted to select the most suitable data and data sources for the wood and wood-processing products in northern Vietnam. Two main indicators were applied for the selection, namely the clear application of concepts and formulae and whether the data are collected by official state organisations. Eight sources of data were finally selected, namely ICARD $([36,44]$, Barney [29], Lamb et al. [37], Nguyen et al. [35], MARD [3], DoF [45] and GSO [14].

Step 2: The concepts in the data published from eight sources were clarified, and reasons why the published data differ were investigated. The concepts of enterprise, factory and sub-industry were developed and defined to 


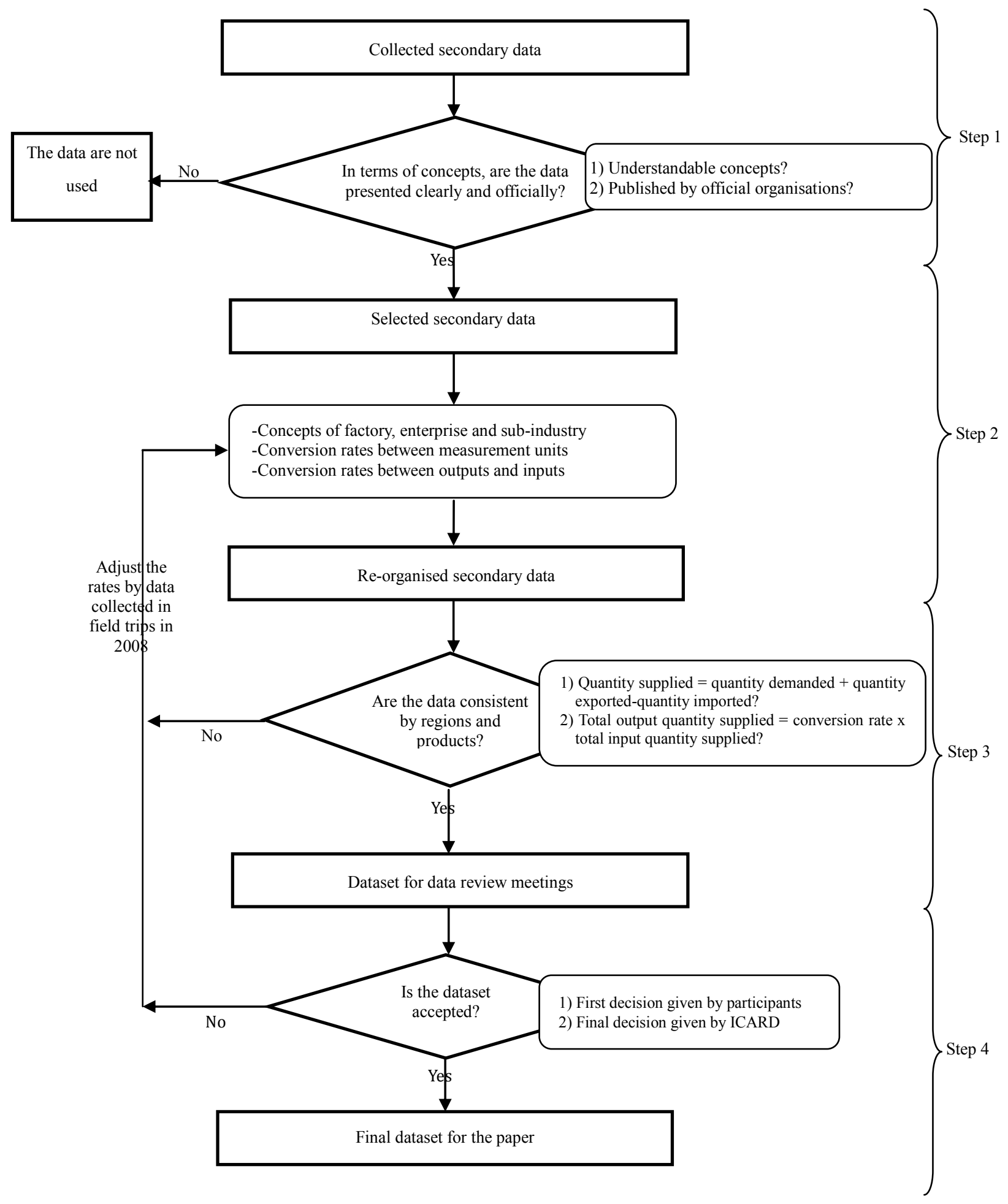

Figure 2. Data collection method.

understand and re-organise published data. Conversion rates between various quantity measurement units used in Vietnam and between quantities of inputs and outputs in. the wood-processing industry in northern Vietnam were examined, and conversions made to standard units

Step 3: Programs were written in the Data Analysis and Statistical Software (STATA) package to classify data according to the new concepts developed and adjusted 
through the conversion rates. The outputs from running these programs include supply quantities, demand quantities and prices in 2008 for products by region in northern Vietnam.

Step 4: Three Data Review Meetings were held in Hanoi city and Quang Ninh province in November 2008 with forestry and statistics experts to obtain comments and make adjustments to the data. A final dataset was agreed by the experts who took part in the Data Review Meetings (and was submitted to Informatics and Statistics Centre for Agriculture and Rural Development (ICARD) as an official dataset to publish).

\section{Establishment of Policy Scenarios}

The four policy scenarios according to four spatial equilibrium models were established basing on three main assumptions. One assumption is northern Vietnam is the small economy; as a result it does not affect the world supply and demand of log and wood-processing products. This assumption was led by the fact that in terms of the percentages of world supplies, the supplies of logs and wood-processing products in Vietnam in general and in northern Vietnam in particular have been very small. According to Brown and Durst [46], in the Asia- Pacific region, the five countries of Japan, China, Indo- nesia, India and New Zealand accounted for 88 percent of wood pulp production. Similarly, the seven countries of Japan, China, Republic of Korea, Indonesia, India, Thailand and Australia accounted for 96 percent of the region's production. According to the estimation of Phan et al. [6], no wood and wood-processing products produced in northern Vietnam could account for more than $3 \%$ of the world supplies in 2008 .

Another assumption is the changes of external factors including international demand and supply from 2008 to 2015 will create good opportunities for the wood-processing industry in northern Vietnam to grow fast. This assumption was led by the fact that almost international economic studies indicated that the growth of forestry and wood-processing industries in Vietnam will be very high by 2020. For example, De et al. [34] esti- mated that the export value of wood and wood-process- ing products in Vietnam will be from 7 - 9 billion USD by 2020 compared to 3.4 billion USD in 2008 [47].

The third assumption is domestic resources like land and capita have not been used effectively in northern Vietnam. This assumption is based on the fact that the studies of ICARD ([33,44]), Barney [29], Karsenty [32] and Dinh et al. [48] indicated that the domestic transaction costs of wood and wood-processing products have been high or the planned spatial locations of new wood-processing factories should be adjusted.
Because of the above three assumptions, the future growth of the wood-processing industry in northern Vietnam will depend mainly on how these resources, for instance the area of planted production forest and the number and scale of wood-processing factories, will be combined effectively together. Therefore, four policy scenarios including internal factors have been developed and examined. Each policy scenario is defined as a group of policies (e.g. building new paper factories and adjusting import taxes) and exogenous variables (e.g. the estimated resident population). The content of each policy scenario is presented in Table 2.

The base policy scenario is used to describe the wood and wood-processing industries in the base year (2008), as presented in Table 2. The differences between the content of other following policy scenarios and that of base policy scenario are mainly expressed by adding new supply functions or shifting the old supply functions of wood and wood-processing products to the right.

The planned policy scenario includes all policies that were planned by the GoV for 1998-2015. For example, in this scenario the construction of eight new pulp and paper enterprises and five new engineered-wood enterprises by 2015 is planned. Import taxes on wood and wood-processing products are 5\%. The annual growth rates of the area of planted production forest, the estimated resident population and income per capita are $6 \%$, $1.5 \%$ and $3 \%$ respectively from 2008 to 2015 . The main policies presented in this policy scenario are summarized in Table 2.

The implemented policy scenario includes only policies that were already implemented in the 1998-2008 period and policies that are going to be implemented in the 2008 2015 period as reported in Phan et al. For example, the paper enterprise being constructed in Tuyen Quang province with the design production capacity of 300,000 tonnes a year is included, as well as the engineered-wood enterprise being constructed in Yen Bai province with the design production capacity of 15,000 tonnes a year. Both of these are expected to be completed by 2015 . The annual growth rate of the area of planted production forest is expected to be $4 \%$ /year in the $2008-2015$ period. Other policy variables and exogenous variables are equal to that in the planned policy scenario (Table 2).

The recommended policy scenario is that established in this study to achieve financial sustainability, and is designed such that the building of any new wood-processing factory will guarantee that all stakeholders can produce and sell their products at profitable quantities and prices in 2015. The process to establish the recommended policy scenario is described in Figure 3. A simple example about how to recommend the optimal design production capacity of a paper factory in Tuyen Quang 
Table 2. Main contents of the four policy scenarios.

\begin{tabular}{|c|c|c|c|c|}
\hline Content & Base policy scenario & $\begin{array}{l}\text { Planned policy } \\
\text { scenario }\end{array}$ & $\begin{array}{l}\text { Implemented policy } \\
\text { scenario }\end{array}$ & Recommended policy scenario \\
\hline Description & $\begin{array}{l}\text { Includes only policies } \\
\text { implemented in the } \\
1998-2008 \text { period }\end{array}$ & $\begin{array}{l}\text { Includes all policies } \\
\text { planned to implement } \\
\text { in the } 1998-2015 \\
\text { period. }\end{array}$ & $\begin{array}{l}\text { Includes only policies } \\
\text { implemented by the GoV } \\
\text { in } 1998-2008 \text { period. }\end{array}$ & $\begin{array}{l}\text { Includes only policies implemented by the GoV } \\
\text { in the 1998-2008 period. } \\
\text { Includes only policies being certainly } \\
\text { implemented between } 2008 \text { and } 2015 \text {. } \\
\text { Includes only policies suggested by the } \\
\text { relationship between prices, production costs } \\
\text { and design production capacities of } \\
\text { wood-processing factories. }\end{array}$ \\
\hline $\begin{array}{l}\text { New } \\
\text { enterprises }\end{array}$ & & $\begin{array}{l}\text { Eight new pulp and } \\
\text { paper enterprises will } \\
\text { be completed and } \\
\text { commence operation } \\
\text { in } 2015 \text {. } \\
\text { Five new } \\
\text { engineeredwood } \\
\text { enterprises will be } \\
\text { completed and } \\
\text { commence operation } \\
\text { in } 2015 \text {. }\end{array}$ & $\begin{array}{l}\text { Tuyen Quang paper en- } \\
\text { terprise with the design } \\
\text { production capacity of } \\
300,000 \text { tonnes a year will } \\
\text { be completed and com- } \\
\text { mence operation in } 2015 \text {. } \\
\text { One engineered-wood } \\
\text { enterprise with the design } \\
\text { production capacity of } \\
15,000 \text { tonnes a year in } \\
\text { Yen Bai province will be } \\
\text { completely and commence } \\
\text { operation in } 2015 \text {. }\end{array}$ & $\begin{array}{l}\text { Tuyen Quang paper enterprise with the design } \\
\text { production capacity of } 350,000 \text { tonnes a year } \\
\text { will be completed and commence operation in } \\
2015 \text {. } \\
\text { One engineered-wood enterprise with the } \\
\text { design production capacity of } 50,000 \text { tonnes a } \\
\text { year in Yen Bai province will be completed and } \\
\text { commence operation in } 2015 \text {. } \\
\text { One engineered-wood enterprise with the } \\
\text { design production capacity of } 50,000 \text { tonnes a } \\
\text { year in Bac Giang province will be completed } \\
\text { and commence operation in } 2015 \text {. } \\
\text { Five woodchip factories with each design } \\
\text { production capacity of } 10,000 \text { tonnes will be } \\
\text { completed and commence operation in Lao Cai, } \\
\text { Lai Chau, Son La, Dien Bien and Ha Giang } \\
\text { provinces }\end{array}$ \\
\hline $\begin{array}{l}\text { Existing } \\
\text { large-scale } \\
\text { enterprises }\end{array}$ & $\begin{array}{l}\text { Design production } \\
\text { capacity of Bai Bang } \\
\text { paper factory was } \\
300,000 \text { tonnes/year in } \\
2008 \text {. } \\
\text { Design production } \\
\text { capacity of Bai Bang } \\
\text { pulp factory is } 165,000 \\
\text { tonnes/year in } 2008 \text {. }\end{array}$ & $\begin{array}{l}\text { Design production } \\
\text { capacity of Bai Bang } \\
\text { paper enterprise will } \\
\text { still be } 300,000 \\
\text { tonnes/year in } 2010 \text {. } \\
\text { Design production } \\
\text { capacity of Bai Bang } \\
\text { pulp factory will be } \\
185,000 \text { tonnes/year } \\
\text { in } 2010 \text {. }\end{array}$ & $\begin{array}{l}\text { Design production } \\
\text { capacity of Bai Bang } \\
\text { paper factory will still be } \\
300,000 \text { tonnes/year in } \\
2015 . \\
\text { Design production } \\
\text { capacity of Bai Bang pulp } \\
\text { factory will be } 185,000 \\
\text { tonnes/year in } 2010 .\end{array}$ & $\begin{array}{l}\text { Design production capacity of Bai Bang paper } \\
\text { enterprise will be } 350,000 \text { tonnes/year in } 2015 \text {. } \\
\text { The operation of existing small-scale paper } \\
\text { factories in Phu Tho and Hoa Binh provinces } \\
\text { will be ceased in } 2015 \text {. }\end{array}$ \\
\hline $\begin{array}{l}\text { Trade } \\
\text { policies } \\
\text { applied for } \\
\text { non-ASEA } \\
\text { N countries }\end{array}$ & $\begin{array}{l}\text { Import taxes on paper } \\
\text { products were } 40 \% \text { in } \\
2008 \text {. } \\
\text { Import taxes on } \\
\text { furniture products were } \\
33 \% \text { in } 2008 \text {. }\end{array}$ & Import taxes on furnitu & products will be $5 \%$ in 2010 . & \\
\hline $\begin{array}{l}\text { Area of } \\
\text { planted } \\
\text { production } \\
\text { forest }\end{array}$ & The base level in 2008 & $\begin{array}{l}\text { The annual growth } \\
\text { will be about } 6 \% \text { per } \\
\text { year in the } 2008-2015 \\
\text { period. }\end{array}$ & \multicolumn{2}{|c|}{ The annual growth will be about $4 \%$ per year in the $2008-2015$ period. } \\
\hline Population & The base level in 2008 & \multicolumn{3}{|c|}{ The annual growth will be $1.5 \%$ from 2008 to 2015} \\
\hline $\begin{array}{l}\text { Income per } \\
\text { capita }\end{array}$ & The base level in 2008 & The annual growth will & $3 \%$ from 2008 to 2015. & \\
\hline
\end{tabular}




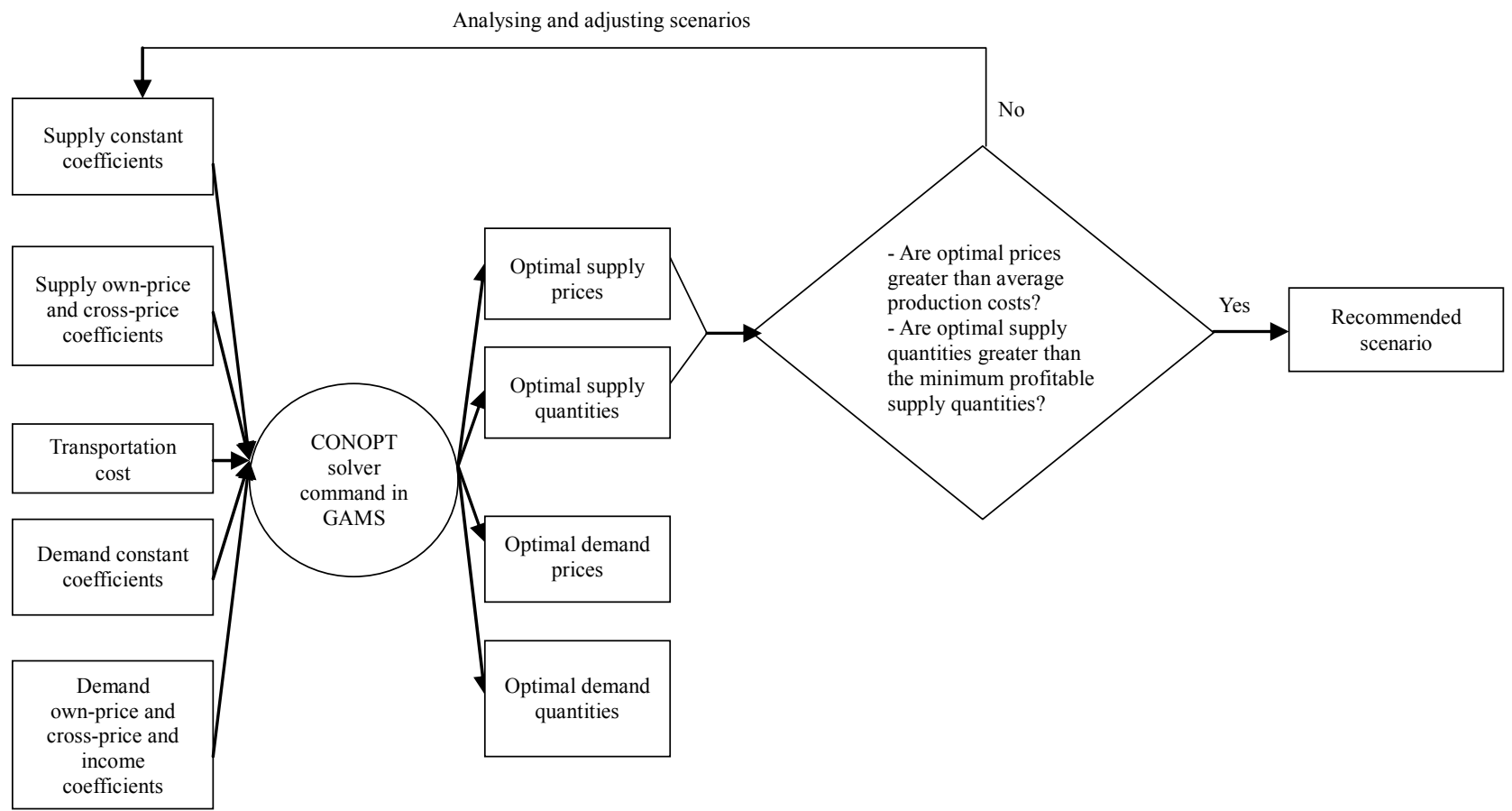

Figure 3. Process to examine the optimal levels and establish the content of building new wood-processing factories for the recommended policy scenario.

province is conducted as in the following steps. A new factory will create a new supply curve of paper in Tuyen Quang province and its first design production capacity (e.g. 200,000 tonnes a year) determines a constant coefficient of the supply curve. The spatial equilibrium model with the first new supply curve identifies the optimal supply price and quantity of paper in Tuyen Quang province. The optimal solution of paper price is compared to the average production cost of 810 USD per tonne. The optimal solution of the paper supply quantity is compared to minimum profitable supply quantity of 130,000 tonnes a year $(200,000 \times 65 \%)^{3}$. If the optimal price is lower than the average production cost or the optimal supply quantity is lower than the profitable supply quantity, the first design production capacity is adjusted to the second design production capacity (e.g. 300,000 tonnes a year). The spatial equilibrium model with the second new supply curve identifies the optimal supply price and quantity of paper in Tuyen Quang province. The optimal price is compared to the average production cost of 760 USD per tonne and the optimal solution of the supply quantity is compared to the profitable supply quantity of 195,000 tonnes a year $(300,000 \times 65 \%)$. This process is continued until the two indicators are satisfied and then the optimal design production capacity of the paper fac-

\footnotetext{
${ }^{3}$ The figure of 0.65 or $65 \%$ is the percentage of minimum profitable supply quantities of wood-processing factories compared to the design production capacities of those factories.
}

tory in Tuyen Quang province is recommended.

A set of indicators has been devised which compares optimal levels of endogenous variables of prices and supply quantities generated with the national average production costs and profitable supply quantities (as presented in Table 3).

In the recommended policy scenario, the paper enterprise under construction in Tuyen Quang province will have the design production capacity of 350,000 tonnes a year in 2015. The engineered-wood enterprise being constructed in Yen Bai province will have the design production capacity of 50,000 tonnes a year in 2015. One new engineered-wood enterprise with the design production capacity of 50,000 tonnes a year will be built in Bac Giang province in 2015. Five new woodchip factories each with design production capacity of about 10,000 tonnes will be completed and commence operation in 2015 in the remote provinces of Lao Cai, Lai Chau, Son La, Dien Bien and Ha Giang. The design production capacity of Bai Bang paper enterprise will be 350000 tonnes/year in 2015. Existing paper factories with the design production capacities of less than 100,000 tonnes a year will cease supplying paper products in 2015. Other variables are equal to that in the implemented policy scenario. The contents of the third policy scenario are summarised in Table 2.

To examine the effect of errors in estimates of elasticities on optimal solutions generated by solving these spa- 
Table 3. Indicators to examine optimal levels of endogenous variables and establish the recommended policy scenario.

\begin{tabular}{|c|c|c|c|c|}
\hline Indicator & Product & Value in 2008 & Source & Note \\
\hline $\begin{array}{l}\text { The average production } \\
\text { cost in } 2008\end{array}$ & Low quality log & 12.12 USD per tonne & {$[33,44]$} & \multirow{4}{*}{$\begin{array}{l}\text { Re-estimated by participants in } \\
\text { the three Data Review Meetings } \\
\text { organised by Phan and his } \\
\text { colleagues in Hanoi city and } \\
\text { Quang Ninh province in } \\
\text { November } 2008\end{array}$} \\
\hline \multirow{2}{*}{$\begin{array}{l}\text { The average production } \\
\text { cost in } 2006\end{array}$} & $\begin{array}{l}\text { Paper produced by Bai Bang } \\
\text { Paper Factory }\end{array}$ & 764 USD per tonne & {$[32]$} & \\
\hline & $\begin{array}{l}\text { Paper produced by factories with } \\
\text { design production capacities of } \\
\text { less than } 300000 \text { tonnes a year }\end{array}$ & $\begin{array}{l}805-842 \text { USD per } \\
\text { tonne }\end{array}$ & [32] & \\
\hline $\begin{array}{l}\text { The profitable supply } \\
\text { quantity }\end{array}$ & Paper and engineered wood & $\begin{array}{l}65 \% \text { of a factory's } \\
\text { design production } \\
\text { capacity }\end{array}$ & [49] & \\
\hline
\end{tabular}

tial equilibrium models, three sets of elasticity levels have been tested for each policy scenario: the external elasticities, all elasticities reduced by $30 \%$, and all elasticities increased by $30 \%$.

\section{The Optimal Solutions and Their Interpretation}

By solving the spatial equilibrium model for the four policy scenarios, four optimal solutions have been generated. These optimal solutions are compared between policy scenarios, supply targets and the two indicators of profitable prices and profitable supply quantities. Two products of low quality logs and paper are selected for these comparisons because the supply quantities of these two products are the most targeted by the GoV's investment policy on building new large-scale state-owned paper factories and expanding the area of planted production forest via the 5MHRP. In addition, the data about average production cost are only available for domestic low quality logs as reported in ICARD $([33,44])$ and Phan et al. [6] and for domestic paper products as reported in Karsenty [32].

\subsection{The Optimal Levels of Prices and Average Production Costs of Low Quality Logs and Paper}

In the planned policy scenario, policies planned by the GoV will lead to two notable outcomes. First, optimal prices of most products in 2015 will be much higher than that in the base policy scenario in 2008, and higher than average production costs, except the optimal price for paper. Table 4 indicates that the selling price of low quality logs will be more than 30 USD per tonne - much higher than the average production cost of about 12 USD per tonne in 2008. Optimal prices in 2015 for low quality logs will be much higher in the provinces having new wood-processing factories including Lai Chau and Son La provinces. Second, eight in 10 paper factories-in- cluding seven of the eight new paper factories-will receive unprofitable prices for their products because optimal prices for paper will be lower than the average production costs of from 805 to 822 USD per tonne respectively in 2006 as reported in Karsenty [32].

In the implemented policy scenario, compared to prices in 2008, optimal prices in 2015 will be higher for woodchip, sawn timber, engineered wood, paper, solidwood furniture and engineered-wood furniture in most provinces in northern Vietnam. Table 5 indicates that the optimal prices of paper products in 2015 will be at least about 852 USD per tonne and that will be much higher than the average production cost for paper products of between 805 and 822 USD per tonne. However, implemented policies will lead to optimal prices in 2015 of low quality logs of not more than the average production cost of about 12 USD per tonne in 2008 in seven provinces in northern Vietnam, namely Son La, Dien Bien, Lai Chau, Lao Cai, Cao Bang, Bac Kan and Ha Giang provinces.

In the recommended policy scenario, compared to prices in 2008, optimal prices in 2015 will be higher for high and low quality logs, woodchip, sawn timber, engineered wood and furniture. An example is optimal prices of low quality logs presented in Table 4. In contrast, optimal prices of pulp and paper in 2015 will be much lower. Optimal prices of all products in 2015 will be higher than the average production costs in all 26 provinces in northern Vietnam. Examples are prices of low quality logs and paper presented in Table 4.

\subsection{Optimal Supply Levels and Factory Design Production Capacities in 2015}

In Table 5, the optimal supply levels in 2015 are compared to factories' design production capacities in percentages. In the planned policy scenario, planned policies result in percentages in 2015 which are mostly lower than the profitable figure of $65 \%$. Planned new paper factories will produce at unprofitable quantities in six prov- 
Table 4. Optimal prices of low quality logs and paper generated by scenarios in relevant provinces (USD per tonne).

\begin{tabular}{|c|c|c|c|c|}
\hline \multirow{2}{*}{ Province } & $\begin{array}{l}\text { Base policy } \\
\text { Scenario }\end{array}$ & $\begin{array}{l}\text { Planned policy } \\
\text { scenario }\end{array}$ & $\begin{array}{c}\text { Implemented } \\
\text { policy scenario }\end{array}$ & $\begin{array}{l}\text { Recommended } \\
\text { policy scenario }\end{array}$ \\
\hline & Prices of low quality logs in 2008 & \multicolumn{3}{|c|}{ Optimal prices of low quality logs in 2015} \\
\hline Ha Giang & 14.3 & 41.9 & 6.4 & 34.5 \\
\hline Cao Bang & 14.4 & 37.2 & 11.6 & 22.5 \\
\hline Bac Kan & 20.9 & 31.2 & 12.2 & 28.8 \\
\hline Lao Cai & 12.0 & 35.2 & 3.3 & 24.5 \\
\hline Dien Bien & 11.9 & 39.5 & 3.3 & 33.0 \\
\hline Lai Chau & 7.9 & 34.2 & 0.0 & 27.7 \\
\hline \multirow[t]{2}{*}{ Son La } & 16.1 & 32.4 & 7.4 & 37.9 \\
\hline & Prices of paper in 2008 & \multicolumn{3}{|c|}{ Optimal prices of paper in 2015} \\
\hline Bac Kan & 837.3 & 787.3 & 863.0 & 808.6 \\
\hline Tuyen Quang & 834.6 & 786.2 & 861.9 & 807.4 \\
\hline Lao Cai & 843.9 & 777.2 & 852.8 & 798.4 \\
\hline Yen Bai & 835.0 & 785.6 & 861.2 & 806.8 \\
\hline Lang Son & 840.7 & 791.0 & 866.6 & 812.2 \\
\hline Bac Giang & 836.0 & 793.6 & 866.6 & 814.9 \\
\hline Phu Tho & 830.5 & 789.8 & 869.3 & 811.0 \\
\hline Dien Bien & 843.9 & 778.2 & 865.4 & 799.4 \\
\hline Lai Chau & 846.9 & 775.6 & 853.8 & 800.7 \\
\hline Son La & 840.9 & 781.4 & 855.1 & 802.6 \\
\hline Hoa Binh & 834.1 & 791.6 & 857.1 & 812.8 \\
\hline
\end{tabular}

Table 5. Optimal supply quantities as percentages of design production capacities by scenarios in relevant provinces.

\begin{tabular}{|c|c|c|c|c|c|c|}
\hline \multirow{2}{*}{ Province or city } & \multicolumn{2}{|c|}{ Planned policy scenario } & \multicolumn{2}{|c|}{ Implemented policy scenario } & \multicolumn{2}{|c|}{ Recommended policy scenario } \\
\hline & Engineered wood & Paper & Engineered wood & Paper & Engineered wood & Paper \\
\hline Hanoi & 58.37 & 0.00 & 62.37 & 0.00 & 63.87 & 0.00 \\
\hline Bac Kan & 118.18 & 58.68 & 0.00 & 0.00 & 0.00 & 0.00 \\
\hline Tuyen Quang & 0.00 & 66.11 & 0.00 & 73.02 & 0.00 & 81.14 \\
\hline Lao Cai & 0.00 & 55.42 & 0.00 & 0.00 & 0.00 & 0.00 \\
\hline Yen Bai & 214.69 & 58.04 & 93.87 & 0.00 & 66.39 & 0.00 \\
\hline Lang Son & 63.59 & 63.21 & 66.21 & 0.00 & 67.88 & 0.00 \\
\hline Quang Ninh & 62.74 & 0.00 & 65.05 & 0.00 & 67.55 & 0.00 \\
\hline Bac Giang & 169.19 & 65.33 & 0.00 & 0.00 & 65.72 & 0.00 \\
\hline Phu Tho & 57.66 & 86.80 & 62.66 & 93.34 & 64.03 & 84.27 \\
\hline Lai Chau & 0.00 & 60.00 & 0.00 & 0.00 & 0.00 & 0.00 \\
\hline Son La & 0.00 & 61.22 & 0.00 & 0.00 & 0.00 & 0.00 \\
\hline Hoa Binh & 117.00 & 86.57 & 62.97 & 93.24 & 64.46 & 0.00 \\
\hline
\end{tabular}


inces, namely Bac Kan, Lao Cai, Yen Bai, Lang Son, Lai Chau and Son La provinces. Engineered-wood factories will produce at unprofitable levels in four provinces, namely Hanoi, Lang Son, Quang Ninh and Phu Tho provinces. In the two extreme cases, engineered-wood factories in Yen Bai and Bac Giang provinces will produce at non-achievable levels, $214 \%$ and $169 \%$ of their design production capacities respectively in 2015 . Overall, almost all planned new wood-processing factories will produce at the level outside the profitable range.

In the implemented policy scenario, nearly all the percentages of the design production capacities of engineered wood factories are mostly lower than the figure of $65 \%$, from about $62 \%$ to just over $65 \%$, except the engineered-wood factory in Yen Bai province with the percentage of $93 \%$ (Table 5). In this scenario, all paper factories will produce at profitable quantities because the corresponding percentages of optimal factory supply quantities compared to their design production capacities will be more than $70 \%$ in 2015 . Nearly all existing and newly constructed wood-processing factories will produce at profitable quantities. Compared to the planned policy scenario, many fewer factories are newly built in the 1998-2015 period. For instance, only one new paper factory is built in Tuyen Quang province while the planned number is nine.

In the recommended policy scenario, the existing stateowned engineered-wood factories in Hanoi, Phu Tho and Hoa Binh provinces will produce at levels that are slightly lower than the figure of $65 \%$ of their design production capacities as indicated in Table 5. All rec- ommended new engineered-wood factories in Yen Bai, Lang Son, Quang Ninh and Bac Giang will produce at profitable quantities (Table 5). Compared to the planned policy scenario, the optimal numbers of recommended new factories are lower and their design production capacities are higher. For example, Table 5 indicates that the number of engineered-wood and paper factories in the planned policy scenario are eight and 10 respectively, compared with only seven and two respectively in the recommended policy scenario. Compared to the implemented policy scenario, the number of recommended new paper factories is unchanged. There is only one new factory in Tuyen Quang province. The number of new engineered-wood factories is higher in the recommended policy scenario - with two factories in Yen Bai and Bac Giang province - than in the implemented policy sce-nario with only one factory in Yen Bai province. Com- pared to the implemented policy scenario, however, all recommended new factories have much higher design production capacities. For example, the design production capacity of Tuyen Quang paper factory is about 300000 and 350000 tonnes a year in the implemented policy scenario and in the recommended policy scenario respectively.

\subsection{Optimal Supply Levels and Supply Targets}

Table 6 summarizes optimal supply levels in 2015 generated by solving the four policy scenarios and compares these optimal levels with supply targets set by the GoV in 2006 for 2015. In the planned policy scenario, the planned policies will lead to optimal supply levels in

Table 6. Optimal supply levels and supply targets by scenario.

\begin{tabular}{|c|c|c|c|c|c|c|c|c|c|}
\hline \multirow[b]{2}{*}{$\begin{array}{l}\text { Product and area of } \\
\text { planted production forest }\end{array}$} & \multirow[b]{2}{*}{ Unit } & \multirow[b]{2}{*}{$\begin{array}{l}\text { Target in } \\
2015\end{array}$} & \multirow{2}{*}{$\begin{array}{l}\text { Quantities } \\
\text { supplied in } \\
2008\end{array}$} & \multicolumn{3}{|c|}{ Optimal supply quantities in 2015} & \multicolumn{3}{|c|}{$\begin{array}{c}\text { Supply quantities in } 2015 \text { relative to } 2015 \\
\text { target }(\%)\end{array}$} \\
\hline & & & & $\begin{array}{l}\text { Planned } \\
\text { policy } \\
\text { scenario }\end{array}$ & $\begin{array}{l}\text { Implemented } \\
\text { policy } \\
\text { scenario }\end{array}$ & $\begin{array}{c}\text { Recommended } \\
\text { policy } \\
\text { scenario }\end{array}$ & $\begin{array}{c}\text { Planned } \\
\text { policy } \\
\text { scenario }\end{array}$ & $\begin{array}{c}\text { Implemented } \\
\text { policy } \\
\text { scenario }\end{array}$ & $\begin{array}{c}\text { Recommended } \\
\text { policy } \\
\text { scenario }\end{array}$ \\
\hline Paper & Mt & 645 & 324 & 1090 & 555 & 621 & 169 & 86 & 96 \\
\hline $\begin{array}{l}\text { Engineered-wood } \\
\text { furniture }\end{array}$ & Mt & 484 & 360 & 401 & 414 & 743 & 83 & 85 & 153 \\
\hline Solid-wood furniture & Mt & 962 & 246 & 278 & 276 & 668 & 29 & 29 & 69 \\
\hline Engineered wood & Mt & 532 & 425 & 659 & 477 & 525 & 124 & 90 & 99 \\
\hline Sawn-timber & Mt & 1480 & 184 & 206 & 206 & 887 & 14 & 14 & 60 \\
\hline Woodchip & Mt & 1591 & 848 & 1947 & 1596 & 1832 & 122 & 100 & 115 \\
\hline Low quality logs & Mt & 2865 & 1259 & 3364 & 1766 & 2792 & 117 & 62 & 97 \\
\hline High quality logs & Mt & 3289 & 410 & 815 & 729 & 778 & 25 & 22 & 24 \\
\hline $\begin{array}{l}\text { Area of planted } \\
\text { production forest }\end{array}$ & 000 ha & 1200 & 334 & 697 & 416 & 595 & 58 & 35 & 50 \\
\hline
\end{tabular}


2015 much higher than the planned quantities of paper and engineered wood but much lower than the planned quantities of sawn timber and solid-wood furniture. The estimation of the optimal area of planted production forest depends on the average productivity of timber. However, the statistical data reported about the average productivity per ha per year of timber trees planted in production forest differs between major data sources in Vietnam, for instance $8-10 \mathrm{~m}^{3}$ in 2000 [29], $20-25 \mathrm{~m}^{3}$ in some province [29], $8 \mathrm{~m}^{3}[33,44,45]$ and $4 \mathrm{~m}^{3} /$ ha/year [14]. According to Phan et al. [6], the average productivities in 2008 were $6 \mathrm{~m}^{3}$ for Eucalyptus spp., $7 \mathrm{~m}^{3}$ for Acacia spp., $5 \mathrm{~m}^{3}$ for Pinus spp., $4 \mathrm{~m}^{3}$ for Bambusoidae spp., and $5 \mathrm{~m}^{3}$ for Styrax tonkinensis. If the average productivity of timber trees in planted production forest in northern Vietnam is about $6 \mathrm{~m}^{3} / \mathrm{ha} /$ year, the area of planted production forest in the planned policy scenario is predicted to be about 658000 ha. This area equals to about $58 \%$ of the area planned by the GoV in 2006 for 2015 .

In the implemented policy scenario, none of the supply targets for 2015 will be achieved, other than for woodchip. The highest percentages of the supply targets will be for paper $(86 \%)$, engineered-wood furniture $(85 \%)$, engineered wood $(90 \%)$ and woodchip $(100 \%)$. The quantities supplied in 2015 of high quality logs, solidwood furniture and sawn-timber will only equal to about $22 \%, 29 \%$ and $14 \%$ respectively of the supply targets. If the average productivity of timber trees in planted production forest in northern Vietnam is about $6 \mathrm{~m}^{3} / \mathrm{ha} /$ year, the area of planted production forest is predicted to be about 412000 ha, equal to $35 \%$ of the area planned in 2006 for 2015.

As percentages of the supply targets, most of the optimal supply levels in 2015 generated by solving the spatial equilibrium model for the recommended policy scenario will be approximately equal to the supply targets, for instance $96 \%$ for paper, $99 \%$ for engineered wood, $97 \%$ for low quality logs, $123 \%$ for pulp and $115 \%$ for woodchip. The optimal supply level in 2015 for engineered-wood furniture will be about $50 \%$ higher than the supply target. The supply quantities planned by the GoV are highly ambitious for high quality logs, sawn timber and solid-wood furniture compared to the growth of these industries in the 1998-2008 period. The supply quantities in 2015 of these products will be still much lower than that planned by the GoV in 1998 for 2015, for instance, $69 \%$ for solid-wood furniture, $60 \%$ for sawn timber, $24 \%$ for high quality logs and $50 \%$ for the area of planted production forest.

\subsection{Sensitivity Analysis}

Most of the above outcomes in each policy scenario hold for the elasticity scenarios of ' $+30 \%$ ' and ' $-30 \%$ '. For the comparisons between optimal prices and average productions costs, most new paper factories will receive unprofitable prices for their products in the planned policy scenario. This outcome will worsen if the average production cost of paper in 2015 is $20 \%$ higher than that in 2008 due to the assumed annual inflation rate of 3.5\% in Vietnam. In this situation, all existing and new paper factories in northern Vietnam will receive unprofitable prices for their products. Similarly, in the implemented policy scenario, optimal prices of low quality logs in 2015 generated for the lower and higher elasticity coefficients will be lower than the average production cost of about 12 USD per tonne in 2008 to produce them in many provinces in northern Vietnam including Son La, Dien Bien and Lai Chau provinces. In addition, if the average production cost of low quality logs in 2015 is $20 \%$ higher than that in 2008 due to the assumed annual small inflation rate of $3.5 \%$ in Vietnam, farmers in 12 provinces in the total of 26 provinces in northern Vietnam would receive unprofitable prices for their products.

The changes of elasticities also have little effect on profitable supply quantities of new engineered-wood and paper factories in northern Vietnam. In the planned and implemented policy scenarios, the optimal levels of supply quantities of engineered wood and paper produced by new factories are all lower than $65 \%$ of their design production capacities.

The only case where the changes of elasticities only have profound effect on optimal supply quantity of solidwood furniture in the planned policy scenario is where $30 \%$ higher elasticities increases the supply of solidwood furniture in northern Vietnam by $47 \%$. This effect is because the solid-wood furniture sub-industry has higher supply price coefficients than those of other subindustries. Since 2000 about $50 \%$ of annual solid-wood furniture outputs of northern Vietnam have been exported [6]. For example, the small changes of supply elasticities in China or those of demand elasticities in USA are predicted to affect profoundly the supply of the solid-wood furniture in northern Vietnam.

\section{Concluding Comments}

The spatial equilibrium analysis indicates that the GoV's historical plans for the forestry and wood-processing industries in northern Vietnam could not be achieved. The conclusion was tested by elasticity changes in each policy scenario. If all policies were implemented in the 2008-2015 period as planned in 2006, most planned new paper factories would receive unprofitable prices for their products in 2015. In the framework of currently implemented policies, the farm-gate prices of logs will 
be lower than the average production costs to produce logs in many provinces in northern Vietnam in 2015. To transit to optimal plans as a longer-run objective, the GoV should adjust the policies planned in 2006 for 2015 and policies implemented in the 2008-2015 period. This would require an increase in design production capacity of existing larger-scale paper and engineered-wood factories. Planned new small-scale paper factories with design production capacities of less than 300,000 tonnes a year and engineered-wood factories with design production capacities of less than 50,000 tonnes a year should not be built. Closure of existing small-scale paper factories of less than 50,000 tonnes by 2015 should be considered. Consequently, the planned area of planted production forest in northern Vietnam should be less much than 900,000 ha, considerably lower than the planned level of about 1.2 million ha.

\section{Acknowledgements}

Funding for this research from a John Allright Fellowship is gratefully acknowledged. I would like to thank Drs Sharon Brown and Peter Dart, at The University of Queensland for their advice and encouragement. I would also like to thank my colleagues working at various state organisations under MARD - including Dr. Trinh Duc Huy, Ms. Nguyen Thanh Huong, Mr. Vu Dinh Xuan, Ms. Vu Huong Thuy, Mr. Pham Duc Thuan, Mr. Le Thanh Van, Mr. An Van Khanh and Mr. Tran Lam Dong-for support in obtaining data and checking the consistency of data presented in this paper.

\section{References}

[1] ICARD (Informatics and Statistics Center for Agriculture and Rural Development), "Assessing the Changes of Institution and Policy from Centrally Planning Economy to Market-Oriented Economy in the past 20 Years," Informatics and Statistics Center for Agriculture and Rural Development (ICARD), Hanoi, 2004.

[2] T. Chakra, "Five Year Plans," 2008. http://www.tradechakra.com/indian-economy/five-year-pl ans/index.html

[3] MARD (Ministry of Agriculture and Rural Development), "Vietnam Forestry Development Strategy 2006-2020," Agricultural Publishing House, Hanoi, 2007.

[4] A. K. Joshi, P. Pant, P. Kumar, A. Giriraj and P. K. Joshi. "National Forest Policy in India: Critique of Targets and Implementation," Small-Scale Forestry, Vol. 10, No. 1, September 2010, pp. 83-96. doi:10.1007/s11842-010-9133-Z

[5] BMoA (Royal Government of Bhutan Ministry of Agriculture), "National Forest Policy," 2008. http://www.moa.gov.bt/moa/downloads/downloadFiles/M oADownload3ea6992sr.pdf
[6] S. H. Phan, H. T. Vu, D. T. Pham and T. V. Le, "Collected and Estimated Data for Wood and Wood-Processing Products in Northern Vietnam," Informatics and Statistics Center for Agriculture and Rural Development (ICARD), Hanoi, 2008.

[7] A .P. Carandang, "Forest Resource Assessment-National Forest Assessment: Forestry Policy Analysis: Philippine," Food and Agriculture Organization (FAO), 2005. http://www.fao.org/forestry/15461-1-84.pdf.

[8] S. H. Phan, "The Changing Administration and the Role of Forestry in the Economy of Vietnam," Small-Scale Forestry, Vol. 3, No 1, 2004, pp. 85-98.

[9] DAFF (Australian Department of Agriculture, Fisheries and Forestry), "Regional Forest Agreements Home," Australian Government, 2008. http://www.daff.gov.au/rfa/.

[10] CMoE (Cambodian Ministry of Environment), "Cambodian National Environment Action Plan 1998 - 2002," 1998.

http://www.camdev.org/_publications/NEAP\%20text-En glish.pdf.

[11] S. H. Phan, H. T. Vu, D. T. Pham and T. V. Le, "Main Characteristics of Statistical Data and the Statistical System for Wood and Wood-Processing Products in Vietnam," Small-Scale Forestry, Vol. 10, No. 2, September 2010, pp. 185-198.

[12] D. Munkhzorig, "Report on National Forest and Water Policy of Mongolia," Ministry of Nature and Environment, 2009.

http://www.rinya.maff.go.jp/faw2002/17\%20D.\%20Mun khzorig\%20(Mongolia).pdf.

[13] D. S. Do and Q. T. Le, "Forest Policy Trends in Vietnam," The Forest Science Institute of Vietnam, Hanoi, 2001.

[14] GSO (General Statistical Office of Vietnam), "Statistical Yearbook 2008," General Statistical Office of Vietnam (GSO), Hanoi, 2008.

[15] GSO (General Statistical Office of Vietnam), "Forest Status Classified by Provinces on 31 December 2008," (Hiện trạng rừng có đến 31/12/2008 phân theo địa phương), 2010.

http://www.gso.gov.vn/default.aspx?tabid=390\&idmid=3 \&ItemID $=8752$.

[16] C. Lang, "Vietnam: Construction of Kon Tum Pulp and Paper Mill Suspended," World Rainforest Movement, Montevideo, Uruguay, 2003. http://www.wrm.org.uy/bulletin/66/Vietnam.html.

[17] C. Lang, "Vietnam: What is Happening in the Pulp and Paper Sector?" World Rainforest Movement, Montevideo, Uruguay, 2006. http://chrislang.org/2007/02/28/vietnam-whats-happening -in-the-pulp-and-paper-sector/.

[18] B. A. McCarl and T. H. Spreen, "Applied Mathematical Programming Using Algebraic System," Department of Agricultural Economics, Texas A\&M University, College Station, 2002.

http://agecon2.tamu.edu/people/faculty/mccarl-bruce/boo 
ks.htm.

[19] D. M. Adams and R. W. Haynes, "The 1980 Softwood Timber Assessment Market Model: Structure, Projections, and Policy Simulations," Journal of Forest Science, Monograph 22 (Supplement to Number 3), 1980, pp. a0001-z0001,

[20] K. S. Jae, "A Spatial Equilibrium Analysis of Southern Pine Lumber Pricing and Allocation," Journal of the Annals of Regional Science, Vol. 19, No. 1, 1984, pp. 61-76.

[21] F. Goletti, A. Raisuddin, N. Minot, P. Berry, B. Romeo, V. H. Nguyen and T. B. Nguyen, "Rice Market Monitoring and Policy Options Study," International Food Policy Research Institute (IFPRI), 1996.

[22] T. Kawaguchi, N. Suzuki and H. M. Kaiser, "A Spatial Equilibrium Model for Imperfectly Competitive Milk Markets," American Journal of Agricultural Economics, Vol. 79, No. 3, 1997, pp. 851-859. doi:10.2307/1244426

[23] A. Yoshimoto and K. Yukutake, "Japanese Forest Sector Modeling through a Partial Equilibrium Model," Forest Resource Use vs. Environmental Policy \& Timber Trade, Vol. 7, No. 1, 2002, pp. 41-48.

[24] ACI (Agrifood Consulting International), "Vietnam Livestock Spatial Equilibrium Model (VILASEM)," the Document for a Training Course at the Informatics and Statistics Centre for Agriculture and Rural Development (ICARD), Hanoi, 2002.

[25] B. Stennes and W. Bill, "An Analysis of Lumber Trade Restrictions in North America: Application of Spatial Equilibrium Model," Canadian Journal of Forest Policy and Economics, Vol. 7, No. 3, 2005, pp. 297-308. doi:10.1016/S1389-9341(03)00067-4

[26] S. Devadoss, A. H. Aguiar., S. R. Shook and J. Araji, “A Spatial Equilibrium Analysis of U.S.-Canadian Disputes on the World Softwood Lumber Market," Canadian Journal of Agricultural Economics, Vol. 53, No. 2-3, 2005, pp. 177-192. doi:10.1111/j.1744-7976.2005.04024.x

[27] S. Katja and S. Jayant, "India's Pulp and Paper Industry: Productivity and Energy Efficiency," Ernest Orlando Lawrence Berkeley National Library, 1999. http://ies.lbl.gov/iespubs/41843.pdf.

[28] GTZ (German Technical Development Cooperation Agency or Deutsche Gesellschaft für Technische Zusammenarbeit), "Enterprises Operating in the Vietnam's Forestry Industry: Current Characteristics and Challenges," (Doanh Nghiep Hoat Dong trong Nganh Lam Nghiep Viet Nam - Hien Trang va Thach Thuc), Presentation at the Forum of Vietnam forestry, 2007.

http://www.vietnamforestry.org.vn/PSC/VN/ForestryInve stmentForum2007/2_GTZ-Forestry percent20Enterprise percent20- percent 20 status percent20\& percent20challenges percent205May07 percent20final percent20draft VN_1.ppt

[29] K. Barney, "Central Plans and Global Exports: Tracking Vietnam's Forestry Commodity Chains and Export Links to China," Forest Trends, Washington DC, 2005.

[30] DoC (General Department of Custom of Vietnam), "Im- port and Export Taxes Applied in 2008," (Bieu Thue Xuat Nhap Khau Viet Nam nam 2008), General Department of Custom of Vietnam (DoC), Hanoi, 2008.

[31] J. M. Roda and R. Santosh, "Feeding China's Expanding Demand for Wood Pulp: A Diagnostic Assessment of Plantation Development, Fiber Supply, and Impacts on Natural Forests in China and in the South East Asia Region, Vietnam Report," Center for International Forestry Research (CIFOR), 2006.

http://hal.cirad.fr/docs/00/19/35/45/PDF/Vietnam.pdf.

[32] A. Karsenty, "Study on the Impacts of Market and Investment Liberalization on Vietnam's Pulp and Plantations Sector, with Particular Reference to China," Vietnam Report, Center for International Forestry Research (CIFOR), 2006.

http://www.cifor.cgiar.org/publications/pdf files/research /governance/foresttrade/Attachment4-CIRAD-VietnamRe port-2.pdf.

[33] ICARD (Informatics and Statistics Centre for Agriculture and Rural Development), "Policies Analysis Matrix for Plantation Forest in Mountainous Regions in Vietnam," Agricultural Publishing House, Hanoi, 2002.

[34] L. De, H. Miyazono, R. Prasad and A. Gerrand, "Regional Implications of National Changes - Some Major Influences," In: R. N. Leslie, Ed., The Future of Forests in Asia and the Pacific: Outlook for 2020, Food Agriculture Organisation (FAO), Chiang Mai, 2007.

[35] N. B. Nguyen, D. Q. Chu, V. T. Duong and H. A. Bui, "Handbook for the Vietnam Forestry," The Handbook was written by the support of the Forest Sector Support Partnership (FSSP) under the Ministry of Agriculture and Rural Development (MARD), Equipment Investment and Printing Joint Stock Company, Hanoi, 2006.

[36] N. B. Nguyen, V. T. Nguyen, C. N. Bui and Q. T. Trinh, "Why do Farmers Choose to Harvest Small-Sized Timber? A Survey in YenBai Province, Northern Vietnam," The Economy and Environment Program for Southeast Asia (EEPSEA), 2006.

http://www.idrc.ca/eepsea/ev-99959-201-1-DO_TOPIC.h tml.

[37] D. Lamb, D. N. Huynh, S. Brown and P. Dart, "Mixed Species Plantations of High-Value Trees for Timber Production and Enhanced Community Services in Vietnam and Australia," Forest Development and the Planting of Native Trees in Three Mountainous Northern Provinces, Project ID: FST/2000/003 Funded by the Australian Centre for International Agriculture Research (ACIAR), 2006.

[38] S. H. Phan and S. Harrison, "A Review of the Formulation and Application of the Spatial Equilibrium Models to Analyze Policy," Journal of Forestry Research, 2011, in Press.

[39] S. H. Phan, "spatequ.gms," Spatial Equilibrium, Model Library section in the Website of General Algebraic Modeling System Development Corporation (GAMS), 2010. http://www.gams.com/modlib/libhtml/spatequ.htm.

[40] J. S. Hseu and B. Joseph, "Output Supply and Input Demand in the Pulp and Paper Industry: A Nonparametric 
Model for the United States and Canada," Journal of Forest Science, Vol. 43, No. 1, 1997, pp. 297-308.

[41] P. McCarthy and L. Lei, "Regional Demands for Pulp and Paper Products," Working Paper, The Center for Paper Business and Industry Studies (CPBIS), 2007. http://www.cpbis.com/research/findings/070604\%20app_ demand_draft.pdf.

[42] T. R. Waggener and L. Christine, "Asia-Pacific Forestry Industry Outlook Study," Working Paper No. APFSOS/ WP/02, International Food and Agriculture Organisation (FAO), 1997. http://www.fao.org/docrep/W4388E/w4388e00.HTM.

[43] J. Turner, K. Andres and B. Joseph, "Implications for the New Zealand Wood Products Sector of Trade Distortions due to Illegal Logging," A Report Prepared for the Ministry of Agriculture and Forestry, New Zealand, 2007. http://www.maf.govt.nz/forestry/illegal-logging/trade-dist ortion-implications/executive-summary.htm.

[44] ICARD (Informatics and Statistics Centre for Agriculture and Rural Development), "Estimated Economic Results of Forest-Growing Households in Dai Tu District, Thai Nguyen Province," The Research Project Funded by Ford Foundation, Hanoi, 2002.

[45] DoF (Department of Forestry), "Introduction to Five Mil- lion ha Program," 2008.

http://dof.mard.gov.vn/661/gioithieu/lydo.htm.

[46] C. Brown and P. Durst, "State of Forestry in Asia and the Pacific-2003: Status, Change and Trends," Food and Agriculture Organisation (FAO), Regional Office for Asia and the Pacific, Bangkok, 2003.

[47] ITTO (International Timber Trade Organisation), "Annual Review and Assessment of the World Timber Situation," International Tropical Timbers Organisation, Yokohama, 2009.

[48] H. K. Dinh and N. S. Vu, "The Plan of Raw Material Area for Paper and Engineered-Wood Production in Vietnam in the 2006-20 Period," (Qui Hoach Cac Vung Trong Nguyen Lieu Giay va Van Nhan Tao Vietnam trong Giai Doan 2006-2020), Specialised Information Bulletin, Informatics and Statistics Centre for Agriculture and Rural Development (ICARD), Hanoi, 2008.

[49] N. Blower, M. H. Ngo, J. Allan, M. Adam, P. David, Q. H. Pham, Q. Derek, Q. Nguyen, T. Mandy, T. B. Do, V. H. Hoang, W. Bob and V. David, "Paper, Prices and Politics: An Evaluation of Swedish Support to the Bai Bang Project in Vietnam," A Swedish International Co-operation Development Agency (Sida) Evaluation Report, Centre for International Economics, 1999. 